音声言語医学 $53: 187-193,2012$

\title{
総説
}

(第 56 回日本音声言語医学会シンポジウム：声帯内注入術一何をどこに：適応と限界）

\section{BIOPEX 注入術}

荒木 幸仁冨藤 雅之鈴木 洋塩谷 彰浩

要 約：当科ではBIOPEX（リン酸カルシウム骨ペースト）を用いた声帯内注入術を施行 している。キットとして市販され準備や注入手技が簡便，すぐ硬化し吸収はきわめて軽微であ り，長期間安定した効果が得られる。硬化する性質を利用し，後部声門閉鎖不良例に対する披 裂軟骨内転効果も期待できる。拡張型喉頭鏡にて喉頭展開を行い，ビデオ喉頭鏡システム下で 注入を行うことで, 声带全体の良好な視野を得ながら器具の干渉も少なく確実な注入が可能と なる，注入後は硬化まで鉗子にて固定し，確実な披裂軟骨内転効果を得ることができる，治療 成績も良好で, 最大発声持続時間・平均呼気流率で有意な改善を認めている。また披裂軟骨内 転効果を生かし，両側声門 BIOPEX 注入による声門閉鎖術を考案し，良好な経過をたどった 症例を紹介する。 BIOPEX 声带内注入術は経口的な甲状軟骨形成術 I 型と披裂軟骨内転術の要 素を併せもった術式であると考えている.

索引用語：声帯内注入術，リン酸カルシウム骨ペースト，BIOPEX，声門閉鎖術

\section{Vocal Fold Injection with Calcium Phosphate Cement (BIOPEX)}

Koji Araki, Masayuki Tomifuji, Hiroshi Suzuki and Akihiro Shiotani

\begin{abstract}
Calcium phosphate bone paste $\left(\mathrm{BIOPEX}^{\circledR}\right)$ is a material for medical use to cover bone defects. It changes from a paste form to hydroxyapatite solid form with time and offers many advantages as a material for vocal fold injection. Preparation and injection procedures are easy because the material is provided in a kit and is a paste form when injected. As material absorption is minimal over a long period, therapeutic effect is stable for long duration. In addition, its solidity after injection enables this material to be used in patients with large posterior glottal gap. The technique we established calls for injection of the material into the lateral side of the vocal process to the adduct arytenoid cartilage using an expandable laryngoscope (FK or Weerda type) and video laryngo-pharyngoscope system. Holding with forceps after injection, to keep the cartilage in good position for a few minutes until the material solidifies, makes this procedure more successful. We also invented a novel trans-oral vocal fold closing method by injecting BIOPEX into both vocal folds taking advantage of arytenoid adduction. Vocal fold injection with BIOPEX in this trans-oral technique has effect similar to thyroplasty type I and arytenoid adduction.
\end{abstract}

防衛医科大学校耳鼻咽喉科学講座 : = 359-8513 埼玉県所沢市並木 3-2

Department of Otolaryngology-Head \& Neck Surgery, National Defense Medical College: 3-2 Namiki, Tokorozawa, Saitama 3598513, Japan

2012 年 1 月 27 日受稿 2012 年 3 月 26 日受理 
Key words: vocal fold injection, calcium phosphate cement, BIOPEX, vocal fold closing

\section{はじめに}

声帯内注入術は 1911 年 Brunings によりパラフィ ン注入が行われて ${ }^{1)}$ 以降, 液状シリコンや脂肪, 筋膜, アテロコラーゲン, ヒアルロン酸などさまざまな注入 物質が試みられてきた。侵襲も少なく，頸部外切開を 要さず整容的に優れ，比較的簡便な術式である，再注 入も可能な場合が多く，患者にとっても多くの利点が ある。ただ注入物質によっては，注入後の組織の異物 反応，肉芽・瘏痕形成，吸収による治療効果の減弱や 持続期間が短いといった問題，生物由来物質の場合は 感染症の危険性，また自家組織を採取するなどの準備 の煩雑さなど，それぞれに長所短所がある。これらの 点を克服可能な注入物質として，われわれはリン酸カ ルシウム骨ペーストに注目した。これは骨補填剤 $\mathrm{BIOPEX}^{\circledR}-\mathrm{R}$ (ペンタックス社, 以下 BIOPEX) とし てキットで市販されている医療用材料であり，準備は 簡便で, 安全性, 効果持続といった点で優れている. 本稿ではBIOPEX 声帯内注入術の詳細や, 最近の治 療効果を高めるための工夫などについて報告する.

\section{リン酸カルシウム骨ペースト（BIOPEX）}

BIOPEX は 2000 年 6 月より国内で販売され，整形 外科, 脳外科, 口腔外科や耳科手術などで骨補填剤と して用いられている，粉剤と液剤を混合し練和するこ とですみやかにぺースト状となり，水和反応によりハ イドロキシアパタイトへと変化する性質を有し, 注入 後生体内にて数分で硬化する。 ハイドロキシアパタイ 卜は人における骨や歯の無機質成分であり，その高い 組織親和性から人工骨として広く臨床応用されてお り，安全性も確立されている物質である。製品はキッ 卜化されており準備は簡単で, ペース卜状で注入も容 易である，など声帯内注入物質として多くの長所を備 えている，異物反応は軽微で，数分で硬化した後はほ とんど吸収されない性質より, 術直後から効果が発現 し，長期的に持続安定する性質を有する。吸収を考慮 する必要はないため, 他の注入物質と異なり過剩に注 入する必要もなく, 気道狭窄などの危険性はきわめて 低い，また硬化する性質より，注入部位を工夫するこ とにより披裂軟骨を内転・固定させる効果も期待でき る。

Ikeda らはウサギにおける BIOPEX 声带内注入の 基礎実験を行い, 注入後 6 力月まで経時的に観察を
行っている. 注入後は喉頭内においてハイドロキシア パタイトとして固形化し，異物反応はごく軽微で，ほ とんど吸収されることなく安定して残存していること を確認した ${ }^{2)}$ 。その結果を基に塩谷らは倫理委員会の 承認を経て 2003 年 8 月より BIOPEX 声帯内注入術の 臨床応用を開始している。これまでに音声機能におい て, GRABSや音響分析検查に扔ける有意な改善効果, および長期経過観察後も吸収されず，安定した効果持 続を認める点, 安全性において問題がない点, などに ついての報告を行っている

\section{BIOPEX 声帯内注入術の適応，手術手技}

主な適応としては嗄声や誤嚥を認める片側反回神経 麻瘏症例に対する声带内方移動術である。近年は声門 後部閉鎖不良症例に打いても，後に述べるように披裂 軟骨内転効果が得られるよう注入手技を工夫しながら 施行し良好な治療成績を得ている，外切開を必要とせ ず低侵襲で特別な術後管理も必要ないため, 全身状態 の不良な症例に打いても十分に適応となりうる。また 披裂軟骨内転効果を応用し，高度嬹下障害に対する新 たな声門閉鎖術として両側声門への BIOPEX 注入術 を考案し, その可能性も検討している.

実際の手術手技は大久保らの報告7) に詳しく述べら れているが，当科では喉頭微細手術同様に可能な範囲 で細径のチューブを経口的に挿管し，基本的に全身麻 酔下で直達喉頭鏡下に経口的に注入する方法で行って いる。 キット付属の専用シリンジに粉剤と液剂入れ, 専用練和器に装着して練和後, ロック付 $1 \mathrm{~m} l$ シリン ジにペースト化したBIOPEX を後方より充填する. シリンジに内筒を挿入し，空気が入らないように満た したうえで，そのシリンジを注入器（ストルツ社製, 型番 27200）に装填する。 17 G $30 \mathrm{~cm}$ のエラスター 注入穿刺針を装着し，針の先端までBIOPEX で満た したうえで注入手技へ移行する。その際に薬㓮, 器具 などを氷で冷却しておくことで, BIOPEX の硬化を 遅らせることができ，余裕をもって注入手技を行うこ とが可能となる。通常は声带突起外側へ注入し披裂軟 骨を内転させ, 声帯膜様部中程外側の甲状披裂筋内ま たは甲状軟骨との間への注入により声帯の体積を増加 させ，声带全体を内方移動させることができる，硬化 する性質より，粘膜直下に注入した場合には声帯粘膜 波動を阻害する恐机があるため，その点は留意が必要 である。術後はほとんど吸収されないため過量の注入 


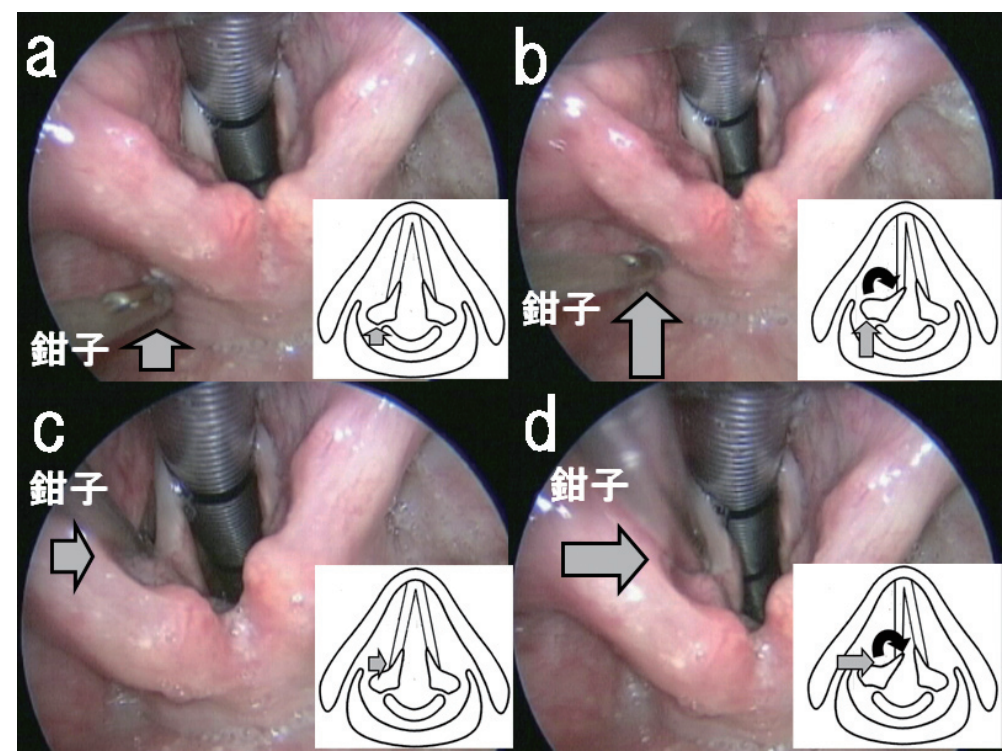

図 1 披裂軟骨内転のシミュレーションと注入部位の決定

鉗子にて披裂軟骨を圧排し内転効果を確認し，BIOPEX 注入部位を決定す る. 披裂軟骨筋突起付近を鉗子にて灰色矢印の方向へ圧排することで, 従 来の披裂軟骨内転術をシミュレートし，披裂軟骨の内転の程度を確認する ( $\mathrm{a}$ ：圧排前, b : 圧排後)。 b では圧排による披裂軟骨内転の結果, 声帯突 起の内転が確認できる.

声带突起外側を鉗子にて灰色矢印の方向へ圧排し, 披裂軟骨筋突起圧排に よる内転時と同様の披裂軟骨内転が得られるか否かを確認する (c: 圧排前, $\mathrm{d}$ ：圧排後). $\mathrm{d}$ では b と同様の披裂軟骨内転効果を認め, 鉗子の圧排部位 付近を BIOPEX 注入部位と決定する.

を行う必要はなく，適切な内転位となった時点で注入 を終了する見極めも重要である。多くの症例では 0.4$0.6 \mathrm{~m} l$ 程度の注入量となっている. 注入後は数分程度 で硬化するため, 注入後 10 分程度経過を観察したう えで手術終了としている.

\section{後部声門閉鎖不良症例での工夫}

従来の声帯内注入術では特に高度な後部声門閉鎖不 良例において, 術後も後方の声門閉鎖が十分改善せず, 音声や嚥下機能の改善効果が不十分となる症例が大き な問題であった，本術式では BIOPEX の注入後に硬 化する性質を利用し，注入部位の工夫などにより披裂 軟骨を内転させる効果も期待できる。そこで近年は後 部声門閉鎖不良症例に対する適応の拡大を目指し，よ り効果的に声带，特に披裂軟骨を内転させる手技への 工夫を重ね，有効性を検討している，新たな手技とし て, 最近は拡張型喉頭鏡（Weerda 型または FK 型） を用いて喉頭展開を行い，ビデオラリンゴスコープを 用いた内視鏡下での注入術を行っている．従来の硬性 喉頭鏡では声帯全長を一視野に収めることは難しく， 特に披裂部方向の良好な視野を得ることは困難である
が，拡張型喉頭鏡を用いて喉頭展開を行うことで声带 全体を一視野におくことが可能となり, working space も通常型硬性鏡よりも拡がる。可能な症例では 喉頭鏡で挿管チューブを前方へ跳ね上げることで，披 裂部を含めた後部声門全体が良好な視野の下にフリー の状態となり, 披裂軟骨の可動性などを詳細に観察し, 内転具合を確認することが容易となる。また内視鏡を 用いることで喉頭全体の立体的な構造が把握しやすく なり，顕微鏡では観察困難となりがちな喉頭室方向や 声門下なども容易に観察できる。さらに内視鏡下の注 入術では注入器具と顕微鏡の干渉も少なく, 刺入した 針の位置や深さなども確認でき, 安全かつ正確に注入 術を行う一助となる ${ }^{8)}$. 以上のような利点を生かし, 最近は多くの症例に拝いて以下のような手技にて注入 術を行っている.

1. 梨状陥凹側より筋突起付近を鉗子にて前方へ圧 排することで，従来の披裂軟骨内転術をシミュレート し, 披裂軟骨の内転具合を確認する（図 1a， b)，2. 続いて声带突起外側の喉頭室を鉗子にて内方へ圧排 し, 筋突起付近の圧排と同様に披裂軟骨が内転するこ とを確認し，注入部位を決定する（図 1c，d）．3．披 


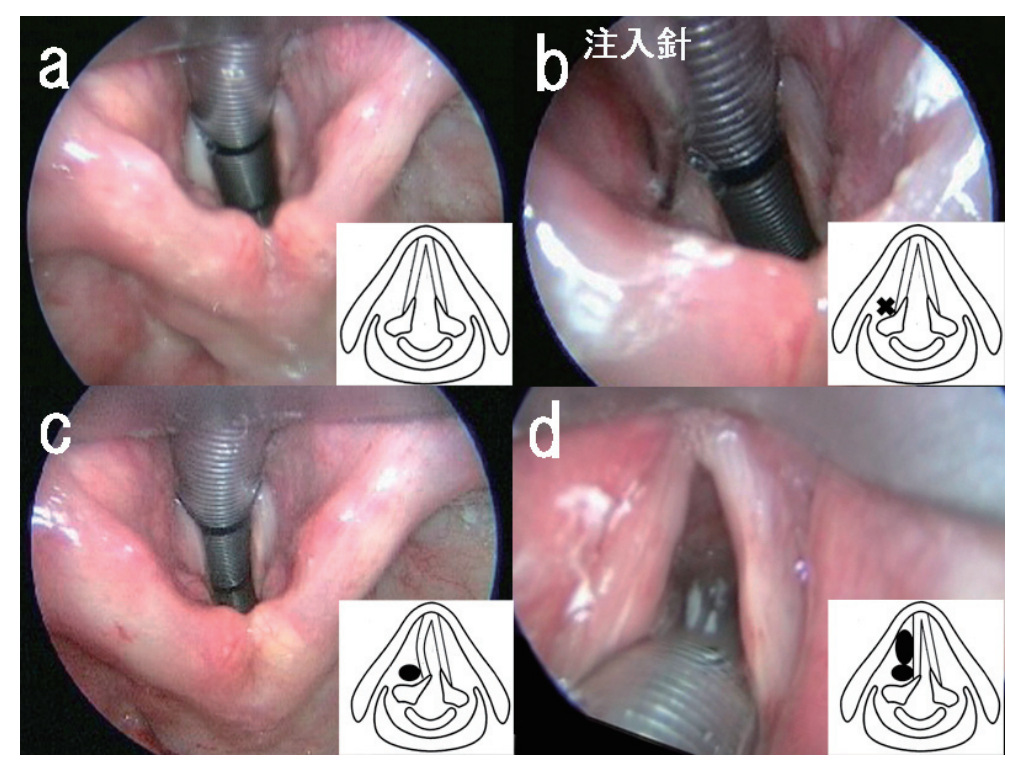

図 235 歳男性, 左声帯内 BIOPEX 注入症例 : 術中所見
$\mathrm{a}$ ：喉頭展開後，挿管チューブを前方へ跳ね上げ声門後方の視野を確保.
b：声帯突起外側へ注入針を刺入し, 注入する様子 ( $\times$ が注入点).
c：注入後披裂軟骨が内転固定している(○が注入物質).
$\mathrm{d}$ ：喉頭再展開の後, 声帯膜様部中央部付近へ注入後
が注入物質)

裂軟骨の内転具合を確認しつつ, 声带突起外側深部に BIOPEX を注入する. 4. 披裂軟骨の内転が適切な位 置となるように鈿子にて圧排し, BIOPEXが硬化す るまで数分間保持する. 5 . 声帯膜様部中央部付近外 側にBIOPEX を注入し, 声帯膜様部を内方移動させ, 硬化まで鉗子で数分間保持する. 以上の方法により, 硬化後は鉗子での圧排を解除しても披裂軟骨は外転せ ず，良好な内転位で固定される。

\section{症例呈示}

35 歳男性, 左特発性反回神経麻瘏

1 年程前より嗄声を自覚し近医耳鼻咽喉科を受診. 左反回神経麻疩を指摘され精査を行うも原因疾患など は認めず, 特発性との診断. 経過観察行うも麻瘏の改 善を認めず，音声改善を希望され加療目的に当科紹介 受診となる。喉頭内視鏡所見では左声帯麻痺, 声帯萎 縮に伴う bowing 拀よび声門後方の閉鎖不全を伴う高 度の声門閉鎖不全を認めた。最長発声時続時間 $(\mathrm{MPT})$ は 3.9 秒, 平均呼気流量 (MFR) は $460 \mathrm{ml} / \mathrm{s}$, G3R0B3A3S0 と高度の嗄声を認めたため, 2011 年 5 月に左声帯 BIOPEX 注入術を施行した. Weerda 型 拡張型喉頭鏡にて挿管チューブを跳ね上げて喉頭展開 を行った（図 2a）、鉗子にて披裂軟骨筋突起㧍よび声 帯突起外側を圧排し, 披裂軟骨の可動性, 内転具合を 確認. 声带突起外側の注入部位を決定し, BIOPEX
約 $0.3 \mathrm{~m} l$ を注入した (図 $2 \mathrm{~b}$ ). 注入後 BIOPEX が硬 化するまで, 針子にて披裂軟骨筋突起側より披裂軟骨 を約 5 分間圧排し, 披裂軟骨が内転位にて固定されて いることを確認した（図 2c)，その後再度喉頭展開を 行い, 捙管チューブを通常の声門後方に戻し, 声帯膜 様部中央部付近外側にBIOPEX 約 $0.2 \mathrm{~m} l$ 注入した. 鉗子にて圧排しながら硬化を数分待ち, 声带全体が適 度に内方移動していることを確認のうえ, 手術終了と した（図 $2 \mathrm{~d}$ )。術直後より音声の著明な改善を認め, 術後 3 カ月の時点で MPT 27.0 秒, MFR $160 \mathrm{ml} / \mathrm{sec}$, GOROBOAOSO と正常な音声へと改善した。視診上, 声門閉鎖は声門後方も含めて完全に改善し（図 3), ストロボスコピーに拀ける声帯粘膜波動の障害も認め ていない.

術後 CT にて BIOPEX が声带外側深部の甲状軟骨 内側に挿入されていることを確認し (図 4), 発声時 の声帯レベル差の改善も認めており, 良好な音声改善 に寄与していると推察された。

\section{治療成 績}

このような工夫を行った 9 症例での結果を示す. 最 大発声持続時間は術前平均 3.94 秒であったものが, 術後 1 力月は 12.91 秒, 術後 3 力月は 15.38 秒, 術後 6 力 月は 15.24 秒と有意に改善を認め (図 $5 \mathrm{a}$ ), また平均 呼気流率においても術前 $590.0 \mathrm{ml} / \mathrm{sec}$ が, 術後 1 カ 


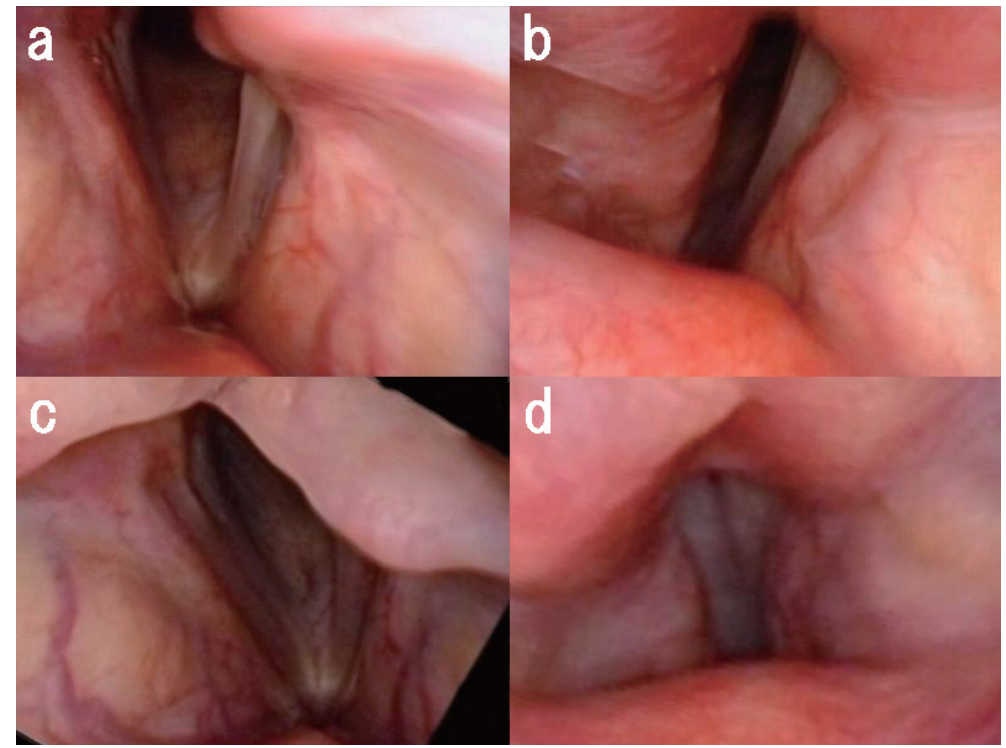

図 335 歳男性, 左声帯内 BIOPEX 注入症例 : 術前後喉頭所見 $a$ : 術前吸気時, $b$ : 術前発声時, $c$ : 術後吸気時, $d$ : 術後発声時. 術前は 発声時の高度声門閉鎖不全，声門後方の開大を認めるが，術後は声門後方 を含め良好な声門閉鎖を認めている。

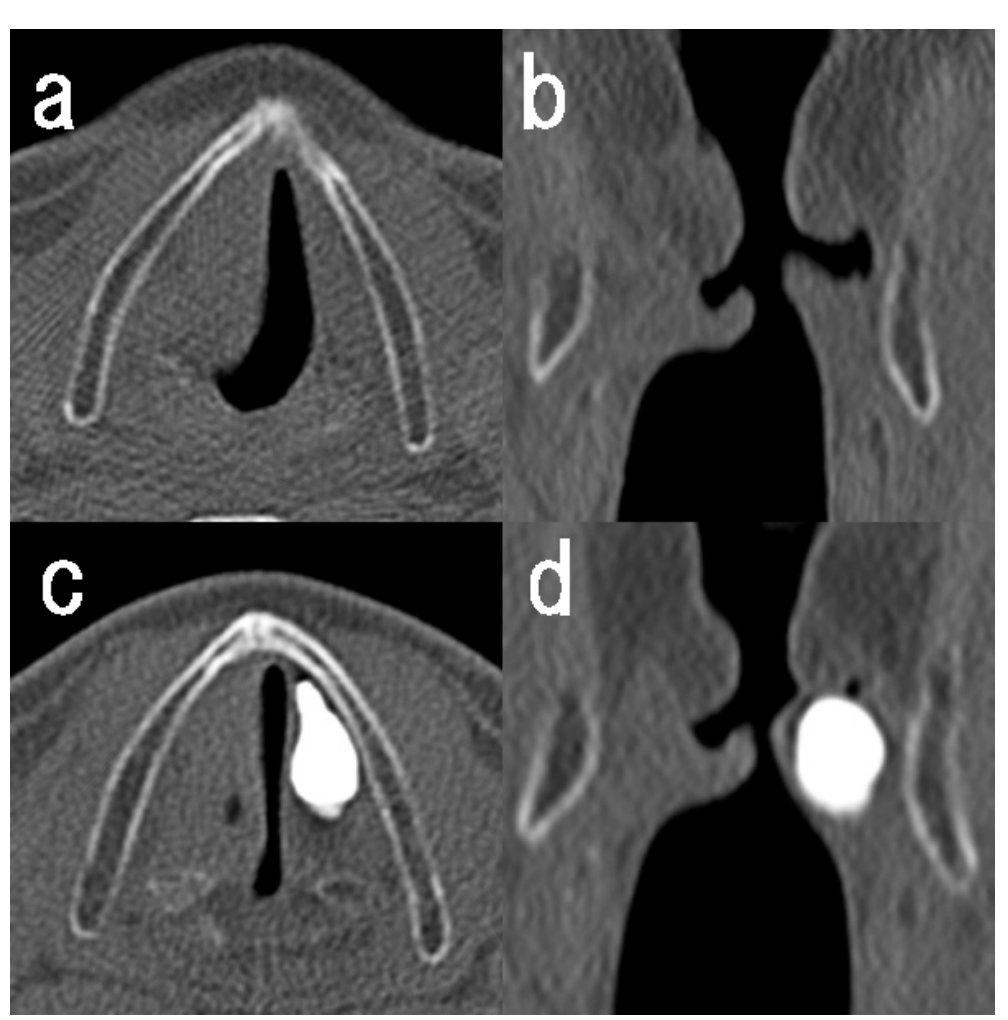

図 435 歳男性, 左声帯内 BIOPEX 注入症例 : 術前後発声時 CT 所見 $\mathrm{a}$ : 術前水平断, $\mathrm{b}$ : 術前冠状断, $\mathrm{c}$ : 術後水平断, $\mathrm{d}$ : 術後冠状断. 術前は 声門後方が開大した高度の声門間隙および声帯レベル差を認めるが，術後 は声門後方を含め左声帯が内転し，声門閉鎖および声帯レベル差の改善を 認める。
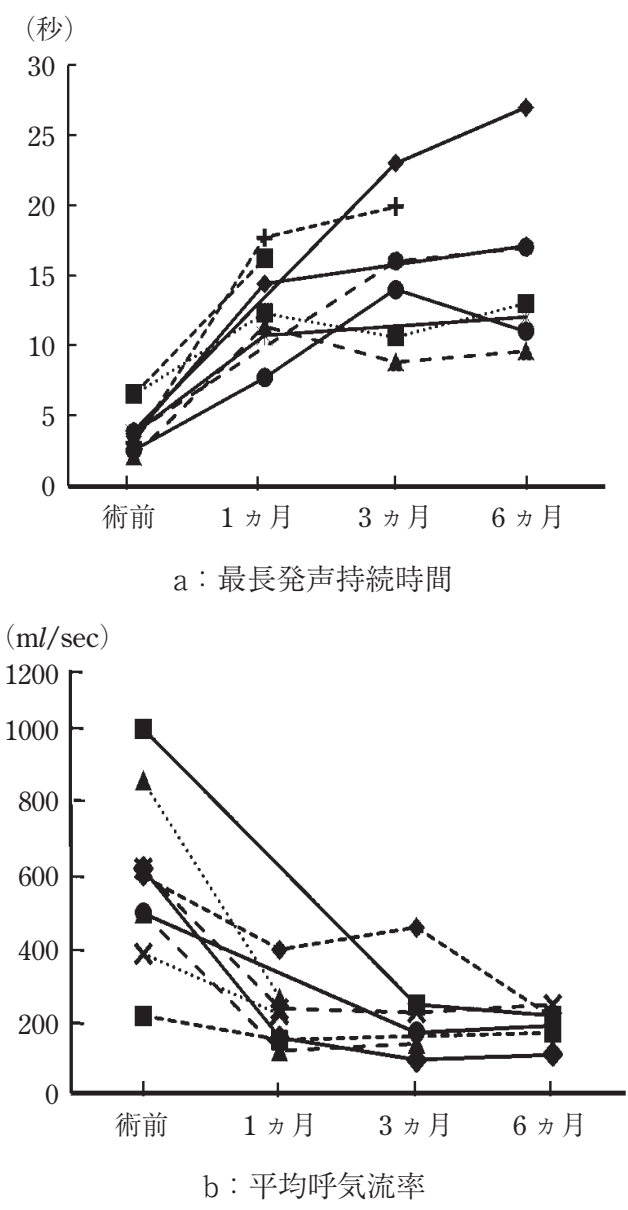

図 5 術前後音声機能 


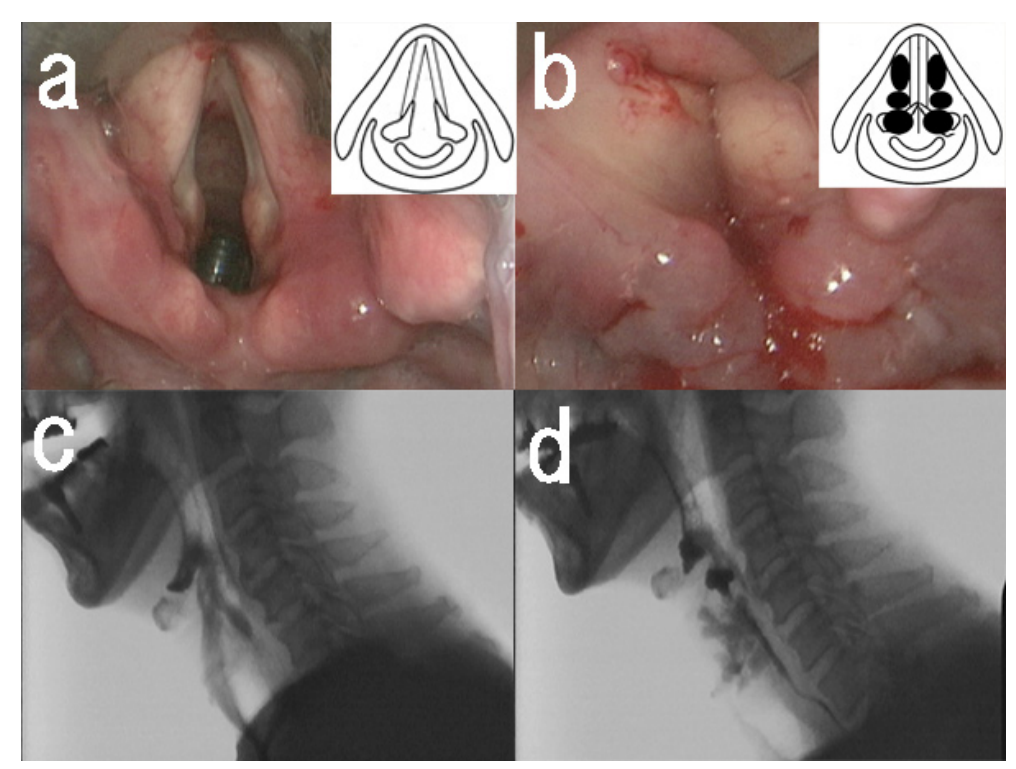

図 6 声門閉鎖術症例

$a$ : 術前喉頭所見, $b$ : 術終了時喉頭所見. 模式図ののの位置にBIOPEX を注入, bでは良好な声門閉鎖を認めている。

$c$ : 術前嚥下造影検査所見, $d$ : 術後燕下造影検査所見. 術前は造影剂の気 管への多量の流入を認めるが (c), 術後は気管への流入は認めず，食道へ の良好な流入を認める (d).

月には $225.0 \mathrm{ml} / \mathrm{sec}$, 術後 3 カ月は $226.7 \mathrm{ml} / \mathrm{sec}$, 術 後 6 カ月において $195.0 \mathrm{ml} / \mathrm{sec}$ と有意に改善を認め ている（図 5b)，多くの症例で良好な後部声門閉鎖の 効果を認め, 治療成績の向上に寄与していると考えら れる。

本術式は経口的な甲状軟骨形成術 I 型であると同時 に経口的披裂軟骨内転術の要素も併せもつ術式である といえる，今後も積極的に症例を重ねるとともに，さ らなる治療成績向上へ工夫を重ねてゆく予定である.

\section{新たな声門閉鎖術への応用の可能性}

上記のように, BIOPEX 注入術は注入部位の工夫 により披裂軟骨内転効果を得ることが可能である。そ こで新たな誤嚥防止手術としての両側声門 BIOPEX 注入による声門閉鎖術を考案し，実際に良好な経過を たどった症例の経験を紹介する。

症例は 71 歳男性. 2007 年に当院神経内科で筋強直 性ジストロフィと診断され, 2010 年から食事量の低 下とともにむせも悪化した。 2011 年 6 月に嚥下性肺 炎を発症し, 嬹下造影検査（VF）では重度の誤嬹を 認めた（図 6c)，原疾患を考慮すると，今後の嚥下機 能回復は困難であり, 経口摂取希望が強いことなどか ら誤嚥防止手術の適応と考え，十分なインフォームド. コンセントを得たうえで, 2011 年 8 月に気管切開術 十 反回神経切断術 +両側声門 BIOPEX 注入術を施行
した. BIOPEX は合計約 $6 \mathrm{~m} l$ 注入し，良好な声門閉 鎖を得ることができた（図 $6 a ， b)$ ，術後 6 日目のVF にて声門閉鎖および誤嚥の著明な改善を確認し（図 6d)，嚥下訓練を行ったうえで術後 18 日目に退院と なっている．現時点では声門前方にわずかな開存を認 めるものの, 鱟下性肺炎の再発は認めて抢らず, プリ ンなど経口摂取が可能となった。術前はほぼ寝たきり で軽度認知障害も認めていたが, 現在は自宅でほぼ自 立した生活を行っており, ADLも著明に改善した。

本術式は新たな経口的誤嚥防止手術として, 低侵襲 で簡便, 安全かつ確実な効果を期待できる。 今後症例 を重ね，その効果と有用性をさらに検討する予定であ る.

\section{まと め}

BIOPEX 声带内注入術は, 主に片側反回神経麻疩 に対する声带内方移動術として施行し, 準備が簡便で, 安全性，効果持続の点でも優れている，その硬化する 性質を利用し披裂軟骨内転効果も期待でき，声門後部 閉鎖不良症例においても良好な治療成績を得ている。 本術式は経口的な甲状軟骨形成術 I 型と披裂軟骨内転 術の要素を併せもった術式といえる。また披裂軟骨内 転効果を利用した高度嚥下障害に対する新たな声門閉 鎖術としての両側声門 BIOPEX 注入術の可能性も今 後検討を重ねてゆく予定である。 


\section{文献}

1) Brünings W: Über eine neue Behandelungsmethode der Rekurrenslamung Verhandl. Ver Deutsch Laryngol, 18: 93-98, 1911.

2) Ikeda A, Shiotani A, Mori Y, et al: Suitability of calcium phosphate cement for injection laryngoplasty in rabbits. ORL J Otorhinolaryngol Relat Spec, 68: 103-109, 2006.

3）塩谷彰浩, 池田麻子, 冨藤雅之, 他：リン酸カルシウム骨 ベースと（BIOPEX）を用いた声帯内注入術。喉頭，16： 127-130, 2004.

4）大久保啓介, 齋藤康一郎, 新鍋晶浩, 他：当院にて施行し た声帯内 BIOPEX 注入術。 日気食会報, 59: 524-533, 2008.

5) Shiotani A, Okubo K, Saito K, et al: Injection laryngoplasty with calcium phosphate cement. Otolaryngol Head Neck Surg, 140: 816-821, 2009.

6）大久保啓介, 塩谷彰浩, 齋藤康一郎, 他：人喉頭における 声帯内 BIOPEX 注入術後の病理組織学的所見. 頭頸部外 科, $16: 187-193,2006$.

7）大久保啓介, 齋藤康一郎, 藤峰武克, 他 : 声帯内注入術の 現状と将来 声帯内 BIOPEX ${ }^{\circledR}$ 注入術. 音声言語医学, 48 : 171-177, 2007.

8）稲垣康治, 齋藤康一郎, 大久保啓介, 他：目盛付き注入針 に内視鏡を併用した声帯内リン酸カルシウム骨ペースト注 入術. 日気食会報，60：314-322，2009.

別刷請求先： = 359-8513 埼玉県所沢市並木 3-2 防衛医科大学校耳鼻咽喉科学講座 荒木幸仁 